UDC 338.24:336.64

O. M. Kovalko ${ }^{1}$, Cand. Sc. (Econ.), Assoc. Prof., orcid.org/0000-0002-4132-8438,

N. M. Kovalko ${ }^{2}$, Cand. Sc. (Jurid.), Assoc. Prof., orcid.org/0000-0001-5550-9267,

O.V. Novoseltsev ${ }^{3}$, Corresponding Member of the

National Academy of Sciences of Ukraine, Dr. Sc.

(Tech.), Senior Research Fellow,

orcid.org/0000-0001-9272-6789

\title{
RESULT-ORIENTED INVESTMENT MANAGEMENT SYSTEM FOR TARGETED ENERGY EFFICIENCY PROGRAMS
}

Purpose. Improving the methodology for managing investments in a targeted energy efficiency program to better attract investment and achieve optimal results at each stage of implementation.

Methodology. Systemic approach has been applied in order to coordinate various stages of developing and implementing the programs, which is based on simulations of iterative procedures of optimal investment management for such programs, and is realized on the basis of the relative organizational and functional autonomy of the programs participants.

Findings. A model is developed that can simulate investment management in energy efficiency; ranking of energy efficiency projects are thus carried out, investment needs are accurately defined, and unanticipated expenditures can be estimated and planned for. The model also provides scenarios for optimal structure, levels of investment, variable interest rates, and use of other economic incentives.

Originality. Methodological approach to increasing the investment management efficiency for targeted programs is improved by integrating in a unified systemic model the financial, economic and energy balances of investment projects submitted to the program by business entities, with subsequent coherent optimization of the parameters of their interaction on the basis of relative organizational and functional autonomy of the entities.

Practical value. The developed simulation model is a powerful tool to support management decisions on identifying and purposeful providing of investments to the most effective directions of targeted programs implementation.

Keywords: energy efficiency programs, investment resources, simulation model in economics, optimal management

Introduction. Energy efficiency is one of the key factors that ensure the sustainable development of advanced world economies for several past decades [1]. This is due to the following reasons:

1. Costs of energy and monetary resources during the life cycle of obsolete equipment exploitation typically exceed the cost of purchase and operation of modern energy efficient equipment.

2. Investments in energy efficiency are more profitable than increasing production capacity to achieve the same development goals.

3. Emissions of carbon dioxide $\left(\mathrm{CO}_{2}\right)$ into the atmosphere are reduced almost proportionally to increase in energy efficiency.

Investments are crucial to improve the operating efficiency of any business. However, for energy-intensive industries especially such as mining and mineral processing (coal, oil, natural gas, peat, and others), and those that produce, transport, distribute and/or sell electricity and heat energy, energy efficiency can be the determining factor as to their survival in a market economy.

However, the current system for investing in EE is outdated and not functional [2], leading to regular difficulty in securing investments in energy efficiency and energy saving (EE) projects. This is a critical problem everywhere and in Ukraine in particular, the lack of

(c) Kovalko O. M., Kovalko N. M., Novoseltsev O.V., 2018 available investment threatens national energy security. An immediate solution is needed.

Analysis of the recent research and publications. Given the timeliness and complexity of the problem, there are a number of researchers who study investment models and mechanisms of EE projects implementation in Ukraine and around the world [1-3].

The researchers have identified tools such as development and implementation of national and regional (sectoral, municipal, and others) energy efficiency programs, establishing EE funds, creation of vertically integrated companies and use of energy service companies (ESCOs). Most of these tools focus on possible combinations (financial, economic, energy, environmental, administrative, and others) of public (national or regional government) and private funding, which provide upfront investment into technologies that reduce system-wide energy use.

The monograph [4] looks at development of a management model for vertically integrated business structures using a case study of a mining and metallurgical facility, as well as interactions between various integrated business units. The publication [5] discusses the role of the national targeted EE programs in harmonizing cooperation between the state, industry and investors to promote economic growth and enhance energy efficiency.

The method for classifying the environmental aspects of investment projects as compared to multi crite- 
rion alternatives is considered in [6]. The monograph [7] uses a case study of high-tech companies and companies with non-implemented innovations in order to highlight the factors that stimulate vertical acquisitions and integration.

The publication [8] considers regulatory models that are harnessed by various countries to attract investments into the energy supply sector to increase efficiency of final energy use. The monograph [1] shows a model of multilevel energy use management in complex production systems with a hierarchical structure, as well as principles of this model building based on the theories of sets and optimal control. Models and mechanisms for attracting investments in EE projects using ESCOs mechanism are analyzed in $[3,9]$.

The results of a comparative analysis these studies show that the most productive tools of managing investments in energy efficiency are the models and mechanisms of task-motivated (task-force) management. These tools are aimed at ensuring consistency of goals and measures in order to improve productive efficiency of business entities (objects of management). Firstly, such models and mechanisms are used in the national (regional, sectoral, and others) targeted programs.

It should be noted that targeted programs play a key role in attracting investments in energy efficiency improvement of business entities in advanced economies. They allow involving resources of state and local budgets besides their own resources of the entities, as well as large strategic investors, including foreign ones, in EE projects financing.

Unsolved aspects of the problem. Despite the global need to solve the problem of energy efficiency improvement and presence of a significant number of government authorities that manage budget resources of energy efficiency programs in almost every country of the world, the results of these programs implementation are still insufficiently attractive to investors. (In Ukraine, these authorities are, above all, the Ministry of Finance, local financial authorities, the Treasury, and others). This situation is largely due to unsolved scientifically methodical and organizational-economic issues of coherent optimization of investment management parameters that should provide efficiency improvement of investment attraction and use process throughout a life cycle of energy efficiency programs.

Objectives of the article. Research goal is improving the methodological framework and building the economic-and-mathematical model of investment resources management for targeted energy efficiency programs that provide increasing efficiency of the investment attraction and use by the way of optimizing their structure and parameters at each stage of these programs implementation coherently.

Achieving the goal was carried out in this research by the way of:

- coordination of interaction between programs participants (business entities and governments), where each participant has their own business interests, which do not always coincide with program goals;
- ranking EE projects submitted by business entities in order to identify opportunities and feasibility of their funding within the program;

- defining economically viable amounts of investments attracted in EE projects as well as parameters of managing by unanticipated expenditures;

- targeted focusing of the efforts of all participants to the improving efficiency of attracted investments use.

Key research findings. Investing in targeted energy efficiency programs associated with the need to overcome certain difficulties, among them, above all, should note the following:

1. Verification of the program effect needs complex calculations of indicators, especially specific costs of fuel and energy resources (FER) associated with production of goods and services.

2. Profit of business entities increases by reducing the expenditure side of their budgets, rather than increasing the revenue side.

3. Schedule return on investments depends on the volumes of money saved through reducing the volume and/or structure of FER consumed.

4. EE projects of separately taken business entity are not usually attractive for foreign investor because of their small size (scale).

5. Managing the investment resources of targeted energy efficiency programs requires coherent solutions of strategic and operational management tasks, as well as problems of tariff and normative regulations, due to specific conditions of implementation and different payback periods of each EE project.

Overcoming the aforementioned difficulties is not easy both methodologically and practically, because each targeted program is multilevel hierarchically structured system of contractual relationships between legally independent business entities, united by a management center (hereinafter - Center) within the program contractual terms.

Combination of business entities' own resources with other possible sources of EE projects financing and their targeted use for implementing the most productive projects is one of the Center priorities. Herewith, the Centre should ensure effective attraction, distribution and use of investment resources based on objective differences of targeted interest of business entities. These require from the Centre to primarily determine the total needs in investment resources and possibilities of their formation by various sources, as well as to develop a simulation model of system coherent management by projects.

Given the size and complexity of building the model of managing the investment resources targeted programs, its realization has been held within the methodology of the project-targeted approach.

The main task of such approach oriented for achieving overall program goals is development of algorithms and procedures for managing just EE projects (project management), rather than production systems of business entities - program participants. This allows, firstly, not to interfere with business activity of participants, and secondly - to concentrate the program resources on to improving management efficiency of EE projects. 
Let the targeted energy efficiency program comprise $\mathrm{n}$ participants - legally independent business entities. In energy, these can be extracting and concentrating companies, as well as companies for production, transport and distribution of electricity and heat. Let them produce $e(e=\overline{1, h})$ different goods (products).

Participation in the program requires from each participant achievement of performance targets concerning the volumes and qualities of production aforementioned goods $\hat{Y}^{e}=\hat{Y}^{1}, \hat{Y}^{2}, \ldots, \hat{Y}^{h}$, as well as targets on volumes and qualities of achieved effects $\hat{E}^{e}=\hat{E}^{1}, \hat{E}^{2}, \ldots, \hat{E}^{h}$.

The effort effectiveness of the program participants at each stage of its realization (for each time period t) and for each product will be determined by the system of normalized indicators $r_{Y, E}^{e}(t)=\left(r_{Y}^{e}(t), r_{E}^{e}(t)\right)$, where $r_{Y}^{e}(t)=Y^{e}(t) / \hat{Y}^{e}(t) ; r_{E}^{e}(t)=E^{e}(t) / \hat{E}^{e}(t) ; e=\overline{1, h}$.

Let the Center be able to attract the capital investments (CI) from different types of funding sources for the program realization

$$
I^{K}=I^{K_{D}}+I^{K_{M}}+I^{K_{A}}+I^{K_{E}}+I^{K_{P}},
$$

where $I^{K}$ is the total volume of attracted CI; $I^{K_{D}}$ is the share of the State budget; $I^{K_{M}}$ is the share of the local budgets; $I^{K_{\dot{A}}}$ is the share of commercial banks; $I^{K_{E}}$ is the share of the ESCOs; $I^{K_{P}}$ is the share of the funds of energy efficient equipment manufacturers.

Let the Center be able to attract the investments $I^{L}$ from other funding sources (additional funds, AF) that are allocated at $L$ goals, primarily at an increase in payroll, compensation of interest rates on commercial banks credits, conducting research and development activities, personnel training, social events and more

$$
I^{L}=I^{L_{D}}+I^{L_{M}}+I^{L_{E}}+I^{L_{P}}+I^{L_{G}},
$$

where the additional funds are denoted by index $G$.

In addition to resources $(1-2)$, it is offered to fill the budget of targeted program with contributions $B^{\Xi}$ of participants that they pay from income obtained as a result of realizing the program measures to improve the efficiency and quality of EE projects realization. Among such contributions, we will distinguish, first, special contributions (SC) of participants from their own funds for development and improving efficiency

$$
B^{\Xi}=B^{K}+B^{L}+B^{Q},
$$

where $B^{K}=\sum \lambda^{K_{j}} V^{K_{j}}$ is the amount of deductions paid to the Center from program participants' own capital investment funds, $V^{K_{j}}$ is the amount of capital investments received by a $j^{\text {th }}$ participant; $B^{L}=\sum \lambda^{L_{j}} V^{L_{j}}$ is the amount of deductions paid by participants for credits received for other goals than capital investments, $V^{L_{j}}$ is the amount of credits received by a $j^{\text {th }}$ participant; $B^{Q}=\sum \lambda^{Q_{j}} E^{Q_{j}}$ is the amount of deductions paid by participants that depends on the value of energy savings $E^{Q_{j}}$ they have achieved under the program, as well as other quantitative, qualitative and environmental im- provements achieved due to realization of program measures; here $\lambda$ with relevant indices determine weight ratios (partial, valuable, and others) that are calculated during the investigated periods (month, quarter, year).

Herewith, it is necessary to note that economically attractive types of funding sources usually have limited and insufficient volumes for implementation of program activities, which requires participants to take participation in partial financing of EE projects.

As a result, the revenue side $I^{\Xi}$ of the total budget $W^{\Xi}$ to the program realization will consist of the following contributions and deductions of participants

$$
I^{\Xi}=I^{K}+I^{L}+B^{\Xi},
$$

and the expenditure side $V^{\Xi}$ of the budget will be determined as

$$
V^{\Xi}=V^{K}+V^{L}+V^{V}+V^{\varphi},
$$

where $V^{K}(t)=\sum V^{K_{j}}(t) ; \quad V^{L}(t)=\sum V^{L_{j}}(t) ; \quad V^{V}(t)=$ $=\sum V^{V_{j}}(t)=\sum v^{Q_{j}} E^{Q_{j}}(t)$ are the amounts of deductions to fund of economic stimulation of the Center staff, which depend on results achieved under the program activities; $V^{\varphi}(t)=\sum \varphi^{Q_{j}} E^{Q_{j}}(t)$ is costs for economic stimulation of other participants (or possible revenues from penalties), which depend on results of their activities. The size of the economic stimulation fund (rewards and penalties) should be limited $V^{V}+V^{\varphi} \leq \delta$.

Taking into account the contribution of participants' own resources (capital, labor, materials, technologies, and others) to manufacturing planned volumes and types of products (services) $Y^{H_{e j}}$ assured quality $E^{H_{e j}}$, revenue part $I^{\Xi H_{j}}$ of the program participant's total budget, which he/she forms for the period of time investigated, will be filled up with the following revenues

$$
I^{\Xi H_{j}}=V^{K_{j}}+V^{L_{j}}+E^{Q_{j}},
$$

and expenditure part $V^{\Xi H_{j}}$ will be defined as

$$
V^{\Xi H_{j}}=V^{H K_{j}}+V^{H \Omega_{j}}+V^{H L_{j}},
$$

where $V^{H K_{j}}$ is the total cost on $j^{\text {th }}$ EE project for logistic support of the technological process (purchasing energy-efficient equipment, consumable materials, spare parts, FER, and others); $V^{H \Omega_{j}}$ is remuneration to the Centre for use of centralized credit resources by participants (with account the amount of rewards or fines); $V^{H L_{j}}$ is cost of additional wages, taxes and more.

Difference $\Delta^{W_{j}}=\left(I^{\Xi H_{j}}-V^{\Xi H_{j}}\right)$ between revenue and expenditure parts of the total budget of the $j^{\text {th }}$ program participant determines its profit, which due to attracting investment resources $\Delta^{W_{j}^{* *}}$ should become more than without their involving $\Delta^{W_{j}^{*}}$. It means that under conditions of effective program management $\Delta^{W_{j}^{* *}}-\Delta^{W_{j} *}>0$. Commonly, this is profit growth of participants after implementation of EE projects which is the main purpose of their participation in the program

$$
\Theta^{H_{j}}=\left(\Delta^{W_{j}^{* *}}-\Delta^{W_{j}^{*}}\right) \rightarrow \max .
$$


According to the conditions noted by abovementioned balance equations $(1-8)$, the task of improving efficiency of the program investment management will consist in selecting numerical values of parameters and coefficients of management influences

$$
\left(I^{K_{j}}, I^{L_{j}}, E^{Q_{j}}, \lambda^{K_{j}}, \lambda^{L_{j}}, \lambda^{Q_{j}}, V^{V_{j}}, V^{K_{j}}, V^{L_{j}}, \Delta^{W_{j}}\right),
$$

at which the program is realized in the best way. Herewith, the Center, which does not take part in production of goods directly, is offered to carry out such management based on one of the following target functionals

$$
\begin{gathered}
\Theta_{1}=\min _{e} \min _{t}\left(\delta^{e}(t) r^{e}(t)\right) \rightarrow \max \\
\Theta_{2}=\left(\sum_{e}\left(\delta^{e}(t) r^{e}(t)\right)\right) \rightarrow \max \\
\Theta_{3}=\sqrt{\sum_{e}\left(\delta^{e}(t) r^{e}(t)\right)^{(2)}} \rightarrow \max
\end{gathered}
$$

where $\delta^{e}$ stands for weight coefficients that are set at conditions of non-equivalence production (consumption) goods by EE projects in different time periods.

Let us remind that the system of equations $(1-9)$ is determined by a multilevel, hierarchically organized structure: Center - program participants - EE projects. Finding solution of this system of equation and its use for optimal program management is complicated and requires the use of a specialized computer tool (model). Herewith, this tool has to solve a set of coordinated optimization problems with different target criteria, which are set by each of the participants that requires using iteration procedures and concessions between the cooperating parties at every structural level of the model.

Since a general method for solving the optimization problem (1-9) for multilevel systems does not currently exist, we apply numerical approach solving this problem by using simulation modeling with variables that are measured in energy and monetary units. Based on the principle of superposition, this allows obtaining the numerical solution of the problem (1-9) in the form of an ordered set of partial solutions coordinated with each other, by operating with information presented in the form of financial-and-economic, fuel-and-energy and environmental balances drawn up for EE-projects. In the generalized kind, these balances are recorded in the form

$$
\sum_{j} \sum_{i} Z^{j, i}=\sum_{j} \sum_{i} \Psi_{z}^{j, i} \cdot P_{z}^{j, i} \cdot T^{j, i},
$$

where $Z^{j, i}$ is the amount of the $i^{\text {th }}$ production resources (money, energy, emissions, and others) on the projects of $j^{\text {th }}$ program participant; $\Psi_{z}^{j, i}$ is capacity utilization rate of $i^{\text {th }}$ resource; $P_{z}^{j, i}$ is capacity of $i^{\text {th }}$ resource; $T^{i, j}$ is the period of time of the resource use.

Methodological approach to improve investment management efficiency of the targeted energy efficiency programs specified by equations $(1-10)$ was implemented in an original computer model. Coordination of the program participants' interaction was made through iterative procedures to minimize the difference between the values of the respective components of the global (at the Center level) and local (at the level of participants) targeted functionals (9). Herewith, the procedure for finding the optimal solution is implemented based on the principle of organizational-and-functional autonomy of participants through the Center's establishing the ranges of allowable changes in parameters of interaction, within which participants are free to choose their own decisions.

The coordination is based on systematic information previously agreed by the parties on the implementation of EE projects, namely regarding: primary energy and material resources used, prices and tariffs for them; volumes of electrical and heat energy produced, prices and tariffs for them; types and values of installed capacity of power equipment, their actual efficiency at rated load, efficiency ratios of primary fuel use, volumes of consumed fuel for their own needs, losses in the electrical and heating networks, heat transfer coefficients of buildings and others; revenue and profitability, volumes of compensation and additional payments; emissions of pollutants into the environment; other information agreed by the parties.

Based on the information received, the Center conducts calculations to determine the optimal structure and parameters of the program realization and defines permissible limits of changing the values of efficiency and quality indicators of EE projects implementation for each participant that have to be achieved under the global targets of the program.

Having this information, participants carry out their optimization calculations, trying to meet the requirements set by the control center. If successful, the process of coordination (reconciliation) ends and the Center goes to implementation stage of the program. If not, the participants substantiate identified differences and submit adjusted proposals to the Center again. It allows finding a compromise solution through iterative procedures and adjustments of the parties' standpoints.

Let us consider the example of practical implementation of the proposed methodology of investment management for targeted energy efficiency programs that is based on cash flow discounting method (dynamic method) in more detail.

Let $n$ EE projects be submitted to the Center, among them at the first step it is necessary to select $m$ projects $(m<n)$ that provide the maximum economic benefit from the program realization under the conditions (1-9) and restrictions on the amount of available investments.

Regarding the proposed algorithm, which is carried out in a computer model, it is done by systemizing and further ranking the results of calculation of the values of net present value and internal rate of return, profitability index and discounted payback period for each of EE project and for the program as a whole.

For example, in Fig. 1 a bar chart shows the results of calculations of feasibility of investment (selection procedure) in 15 most effective from 36 EE projects submitted to the Center, ranked by the profitability index (PI). Volumes of necessary investments are indicated with triangular markings in Fig. 1 and are measured by right ordinate axis. 


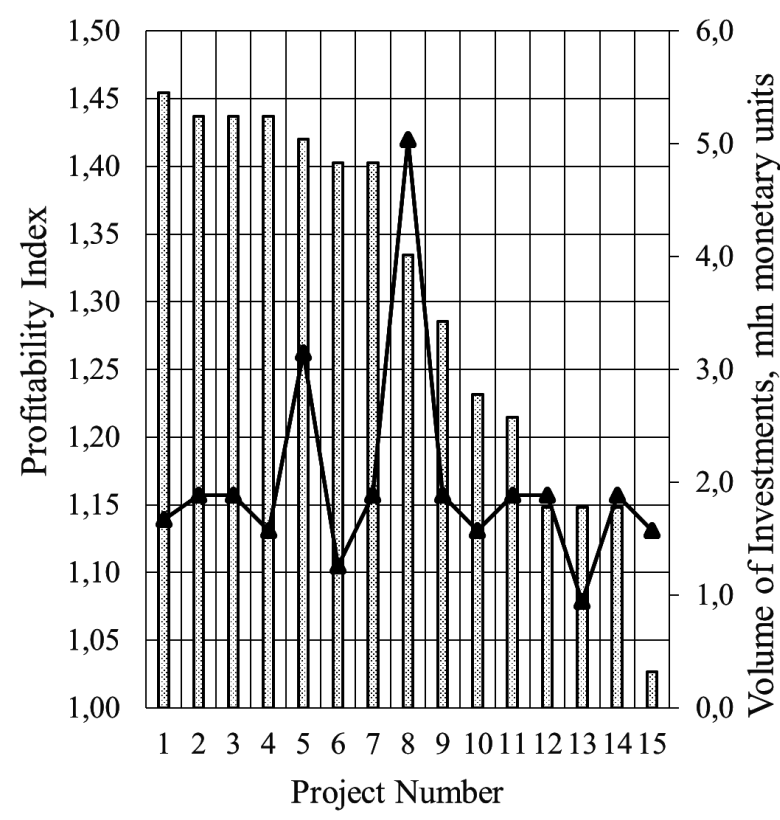

Fig. 1. Ordered set of EE projects ranked by the profitability index

From the data presented in Fig. 1 it is not difficult to calculate that the total volume of investments required to implement 15 selected $\mathrm{EE}$ projects is equal to 30.00 million monetary units, and the total net present value of the selected projects -9.00 million monetary units. Herewith, the value of interest payment on credits, calculated by annuity payment schedule, amounts to 9.63 million monetary units at an annual interest rate of $12 \%$.

This size of the rate was achieved by potential participants of the program through their direct negotiations with creditors. The size is not optimal and can be reduced through systemic management by investment resources of the program. Under the proposed algorithm this is achieved by optimizing the structure and parameters of all available funding sources (1-3) under the criterion of minimizing the total amount of the cost of servicing credit obligations within existing restrictions on available funding for each of the sources.

The results of optimization of the structure and volumes of investment resources attracted from different sources at different interest rates, and the size of payments for each borrowing are presented in Fig. 2. The borrowings in Fig. 2 are denoted with an additional symbol "+", others explanation can be seen in formulas (1-3).

From the data in Fig. 2 it is not difficult to calculate that the estimated size of annual interest rate is reduced and amounts to $10.5 \%$, and the amount of interest payments -8.32 million monetary units. Thus, using systemic management of investment resources attracted by the Centre within the program framework, savings through economies of scale reached to 1.31 million monetary units only on interest payments.

At the same time, operational issues of economic stimulation (using of rewards and penalties) of participants are resolved at the level of Center managing in- vestment resources of the program. In the process of realizing the program for various reasons, there occurs a demand for additional financing of some projects to achieve the program objectives on the volumes and qualities of reached effects and/or for additional remuneration of participants, whose performance indicators exceed targets.

Let the additional costs occur in the implementation of the $1^{\text {st }}, 2^{\text {nd }}, 9^{\text {th }}$, and $12^{\text {th }}$ EE projects, whose efficiency measured by PI-index decreased in comparison with the planned accordingly by $20.0,15.5,9.8$ and $29.8 \%$, while the performance of the $7^{\text {th }}$ and $14^{\text {th }}$ projects increased by 19.9 and $10.1 \%$ (Fig. 3).

Under the proposed management methodology, additional costs incurred should be compensated either from the reserve fund of the Center, or covered by the

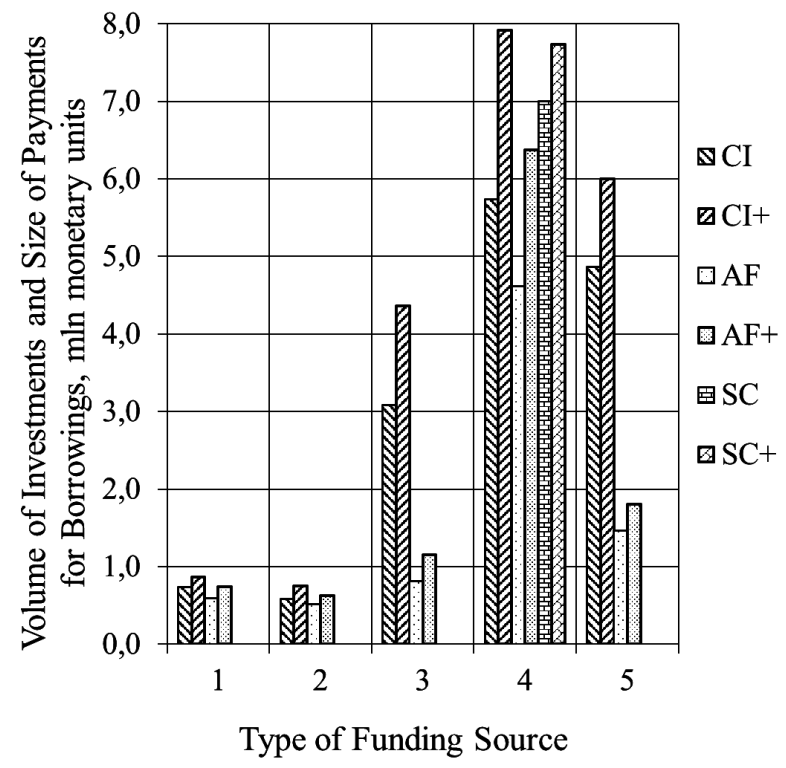

Fig. 2. Optimized structure of funding sources

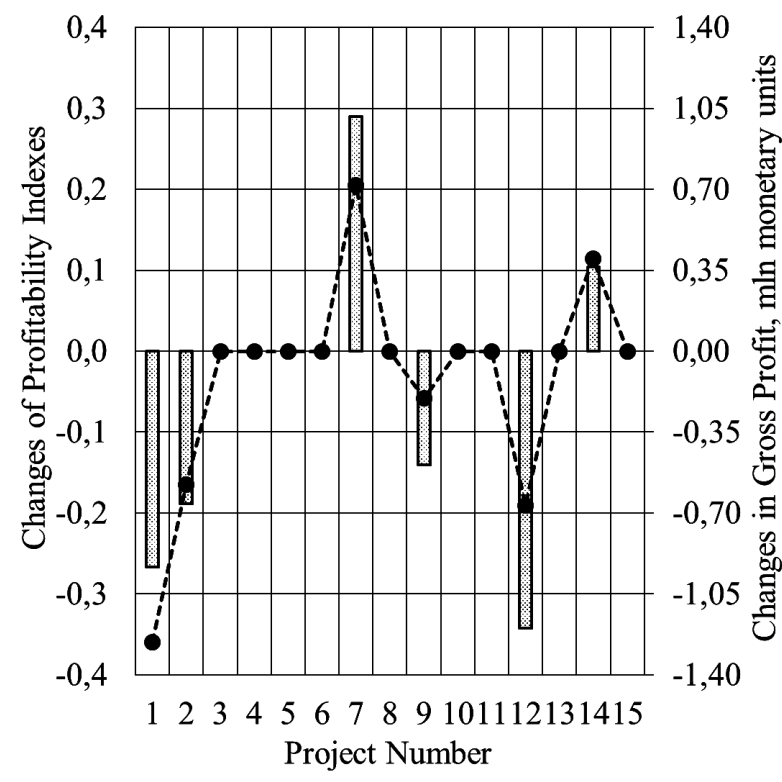

Fig. 3. The results of optimization the operational management indicators 
participants' own funds, as well as additional revenues should be reallocated according to the expressions (3-7), in order to provide balancing of the interests of the Center and participants under the conditions (8).

The results of the operational management by additional costs of investment resources received by optimizing their volumes are presented in Fig. 3 as changes in the volumes of the gross profit that are achieved through the relevant EE projects. Under the whole program, these costs increased by 2.30 million monetary units, and gross profit decreased by 1.60 million monetary units.

For comparison, in the absence of operational management by additional costs, the total gross profit decrease by 2.91 million monetary units. That is, the operational management by investment resources of the program allows reducing the loss in gross profit by $1.31 \mathrm{mln}$ monetary units.

The total gain from realization of the proposed methodology of investment resources management on the case study of 15 typical EE projects reaches $1.31+$ $+1.31=2.62$ million monetary units, or $8.7 \%$ of the planned investments under the program.

Conclusions and recommendations for further research.

1. Creating conditions for investment attraction in targeted energy efficiency programs is a priority for sustainable economic development of any country, whose successful solution depends on the coordinated efforts of public authorities, regulators and business entities. For the last ones this problem is particularly important because the lack of investment for them means a loss of income and reduces the competitiveness of products.

2. The proposed methodological approach to the management of investment resources achieves this goal and obtains results provided by the targeted programs through systemic coherent optimization of investment costs. In order to achieve success, these costs should take into account the financial, economic and energy indicators of efficiency using the capital investment funds of all program participants proportional to the investment resources they receive from the Center, and applying the functions of economic incentives and resource management depending on way of these funds use.

Prospect for further development of research in this area is to develop methodical guidelines for public authorities, regulators and business entities to improve the efficiency of investment management for targeted programs.

\section{References.}

1. Kovalko, O.M., Novoseltsev, O.V. and Evtukhova, T. O., 2014. Introduction to the Energy Efficiency Theory of Multilevel Systems: Methods and Models of Energy Management in Housing and Municipal Economy. Kyiv: Institute of Engineering Thermo Physics, Ukraine.

2. Cabinet of Ministers of Ukraine, 2015. The National Action Plan on Energy Efficiency for the period 2020 (2015), Decree of Cabinet of Ministers of Ukraine of 25.11.2015 № 1228-r.
3. Naceur, K. B., 2015. Market Trends and MediumTerm Prospects. Paris: IEA Publications.

4. Skopenko, N. S., 2014. Methodical approaches to the determination of expediency and efficiency of integration interaction of business entities. Stratehiya ekonomichnoho rozvytku Ukrayiny, 34, pp. 163-170.

5. Schiller, S. R., 2012. Energy Efficiency Program Impact Evaluation Guide. Golden, Colorado: National Renewable Energy Laboratory [pdf]. Available at: <https:// www.energy.gov/sites/prod/files/2013/11/f5/emv_ee program_impact_guide.pdf $>$ [Accessed 17 March 2017].

6. Shvets, V.Ya., Rozdobutko, E.V. and Solomina, G. V., 2013. Aggregated Methodology of Multicriterion Economic and Ecological Examination of the Ecologically Oriented Investment Projects. Naukovyi Visnyk Natsionalnoho Hirnychoho Universytetu, 3, pp. 139-144. 7. Fresard, L., Hoberg, G. and Phillips, G., 2015. Innovation Activities and the Incentives for Vertical Acquisitions and Integration. Baltimore: University of Maryland.

8. Swanson, S., 2012. Regulatory Mechanisms to Enable Energy Provider Delivered Energy Efficiency. Montpelier: RAP Publications [pdf]. Available at: <https://www. iea.org/media/workshops/2012/pepdeebrussels/RAP Swanson2012_March.pdf> [Accessed 5 February 2017]. 9. Novoseltsev, O., Kovalko, O. and Evtukhova, T., 2013. Cross-border cooperation of energy service companies as a factor enhancing energy and economic safety. In: G. Pivnyak, O. Beshta, and M. Alekseyev, eds., Energy Efficiency Improvement of Geotechnical Systems. London: Taylor \& Francis Group, CRC Press. pp. $37-46$.

\section{Орієнтована на результат система управління інвестиційними ресурсами цільових програм з енергоефективності}

\section{О. М. Ковалко ${ }^{1}$, Н. М. Ковалко ${ }^{2}$, О. В. Новосельцев ${ }^{3}$}

1 - НАК „Нафтогаз України“, м. Київ, Україна, e-mail: omkovalko@gmail.com

2 - Київський національний університет імені Тараса Шевченка, м. Київ, Україна, e-mail: kovalkonata@ukr.net 3 - Інститут технічної теплофізики НАН України, м. Київ, Україна, e-mail: anovos773@ukr.net

Мета. Удосконалення методології управління інвестиційними ресурсами цільових програм 3 енергоефективності, що забезпечує підвищення ефективності залучення й використання інвестицій за рахунок оптимізації їх структури та параметрів на кожному з етапів реалізації програм.

Методика. Полягає в застосуванні єдиного підходу до формалізації системно узгоджених етапів розробки й реалізації цільових програм, що базується на імітаційному моделюванні ітераційних процедур оптимального управління інвестиційними ресурсами такого роду програм, реалізованих за принципом відносної організаційно-функціональної самостійності учасників.

Результати. Побудована економіко-математич- 
на модель управління інвестиційними ресурсами цільових програм, проведене ранжування проектів 3 енергоефективності, визначені обсяги економічно доцільного залучення інвестицій у такі проекти, розроблено алгоритм управління непередбаченими витратами. Показані можливості підвищення ефективності реалізації цільових програм шляхом оптимізації структури та обсягів інвестиційних ресурсів, залучених із різних джерел за різними відсотковими ставками, та застосування системи економічного стимулювання учасників програм.

Наукова новизна. Удосконалено методологічний підхід до підвищення ефективності управління інвестиційними ресурсами програм з енергоефективності за рахунок інтеграції в єдиній моделі фінансово-економічних і енергетичних балансів інвестиційних проектів, представлених до програми господарюючими суб'єктами, з подальшою узгодженою оптимізацією параметрів їх взаємодії за принципом відносної організаційно-функціональної самостійності.

Практична значимість. Розроблена економікоматематична модель є потужним інструментом підтримки управлінських рішень щодо визначення й цілеспрямованого забезпечення інвестиціями найбільш ефективних напрямів реалізації цільових програм.

Ключові слова: програми з енергоефективності, інвестиційні ресурси, економіко-математична модель, оптимальне управління

\section{Ориентированная на результат система управления инвестиционными ресурсами целевых программ по энергоэффективности}

\section{А. М. Ковалко ${ }^{1}$, Н. Н. Ковалко ${ }^{2}$, А. В. Новосельцев ${ }^{3}$}

1 - НАК „Нафтогаз Украины“, г. Киев, Украина, е-mail: omkovalko@gmail.com

2 - Киевский национальный университет имени Тараса Шевченко, г. Киев, Украина, e-mail: kovalkonata@ukr.net 3 - Институт технической теплофизики НАН Украины, г. Киев, Украина, e-mail: anovos773@ukr.net

Цель. Совершенствование методологии управления инвестиционными ресурсами целевых программ по энергоэффективности, которое обеспечивает повышение эффективности привлечения и использования инвестиций путем оптимизации их структуры и параметров на каждом этапе реализации программ.

Методика. Заключается в применении единого подхода к формализации системно согласованных этапов разработки и реализации целевых программ, который базируется на имитационном моделировании итерационных процедур оптимального управления инвестиционными ресурсами такого рода программ, реализуемых по принципу относительной организационно-функциональной самостоятельности участников.

Результаты. Построена экономико-математическая модель управления инвестиционными ресурсами целевых программ, проведено ранжирование проектов по энергоэффективности, определены объемы экономически целесообразного привлечения инвестиций в такие проекты, разработан алгоритм управления непредвиденными расходами. Показаны возможности повышения эффективности реализации целевых программ путем оптимизации структуры и объемов инвестиционных ресурсов, привлеченных из разных источников по разным процентным ставкам, и применения системы экономического стимулирования участников программ.

Научная новизна. Усовершенствован методологический подход к повышению эффективности управления инвестиционными ресурсами программ по энергоэффективности путем интеграции в единой модели финансово-экономических и энергетических балансов инвестиционных проектов, представленных в программу хозяйствующими субъектами, с последующей согласованной оптимизацией параметров их взаимодействия по принципу относительной организационно-функциональной самостоятельности.

Практическая значимость. Разработанная экономико-математическая модель является мощным инструментом поддержки управленческих решений по определению и целенаправленному обеспечению инвестициями наиболее эффективных направлений реализации целевых программ.

Ключевые слова: программы по энергоэффективности, инвестиционные ресурсы, экономико-математическая модель, оптимальное управление

Рекомендовано до публікації докт. екон. наук М. М. Ільчуком. Дата надходження рукопису 25.04.17. 